\title{
HIV Integrase Inhibitor
}

National Cancer Institute

\section{Source}

National Cancer Institute. HIV Integrase Inhibitor. NCI Thesaurus. Code C157401.

An agent that blocks the activity of the human immunodeficiency virus (HIV) integrase enzyme. 